\title{
Konferencja naukowa „Organizacja Todt i praca przymusowa w czasie II wojny światowej" (Organisation Todt og tvangsarbeid under okkupasjonen) w Narviku (Norwegia)
}

W dniach 14-15 maja 2013 r. odbyła się w Wyższej Szkole (Høgskolen) w Narviku konferencja naukowa, zorganizowana przez narwickie Centrum Naukowe (Narviksenteret) i Norweski Uniwersytet Techniczno-Przyrodniczy (Norges teknisk-naturvitenskapelige universitet $=$ NTNU) $\mathrm{w}$ Trondheim. Było to pierwsze seminarium naukowe, a zarazem pierwsze spotkanie uczestników projektu naukowego pt. „Ekonomia polityczna pracy przymusowej: Organizacja Todta w Norwegii w czasie II wojny światowej" (Tvangsarbeidets politiske økonomi: Organisation Todt i Norge under 2. verdenskrig), realizowanego przez historyków norweskich $\mathrm{z}$ w/w Uniwersytetu w Trondheim, a także Uniwersytetu w Tromsø, Uniwersytetu Agder w Kristiansand i kilku innych instytucji naukowych oraz z zagranicy. Praca nad projektem ruszyła jesienią 2011 r. i jest finansowana przez Norweską Radę Badawczą (Norges Forskningsråd) w Oslo. Celem seminarium było zaprezentowanie dotychczasowych rezultatów badań, skoordynowanie dalszych prac i poszukiwań, tak aby projekt mógł być w terminie zakończony. Warto podkreślić, że w badania nad tym nowym zupełnie dla historyków norweskich zagadnieniem zostało zaangażowanych wielu młodych adeptów historii - magistrantów i stypendystów (odpowiednik doktoranta) oraz pracowników naukowych z kilku muzeów norweskich, zajmujących się problematyką II wojny światowej.

W pierwszym dniu obrad, w sesji I jako pierwszy z referatem wystąpił absolwent studiów historycznych Simon Gogl z Freie Universität Berlin. Zaprezentował on swoje badania na temat powstania Grupy Operacyj- 
nej Wiking w Norwegii („Om opprettelsen av Einsatzgruppe Wiking”), określając główne powody dla których Einsatzgruppe Wiking powstała ostatecznie dopiero w kwietniu 1942 r. Kolejny referent, Kjetil Gjølme Andersen z Norweskiego Muzeum Technicznego (Norsk Teknisk Museum) w Oslo, przedstawił w szerszym zakresie problem utworzenia Grupy Operacyjnej Wiking, ukazując istotne dla zaistnienia odrębnej struktury OT w Norwegii personalne rozgrywki między kierownictwem OT a Hitlerem. Następne wystąpienia I sesji poświęcone były poszczególnym dziedzinom gospodarki, w tym zwłaszcza rozbudowy infrastruktury i fortyfikacji w Norwegii. Pierwszy referat $\mathrm{z}$ tej serii wygłosił stypendysta z NTNU i pracownik Wojennej Szkoły Lotniczej (Luftkrigsskolen) w Trondheim Torgeir Severaas, prezentując swoje badania na temat budowy przez OT ciężkich baterii wzdłuż wybrzeża Norwegii. Kolejny referat przedstawili wspólnie profesor NTNU Hans Otto Frøland i jego magistrant Anders Lervold na temat ważnych inwestycji III Rzeszy w Norwegii, jakimi były fabryki aluminium budowane przez spółkę akcyjną A/S Nordag z wykorzystaniem siły roboczej dostarczanej przez OT.

W sesji II tego samego dnia zaprezentowano kolejne tematy z zakresu problematyki związanej z polityką ekonomiczną III Rzeszy wobec okupowanej Norwegii. Od kwietnia 1942 r. głównym wykonawcą zadań budowlanych w Norwegii, jak wspomniano, została samodzielna Grupa Operacyjna pod nazwą OT-Einsatzgruppe Wiking, dysponująca niezależną administracją w Norwegii, podległą jedynie centrali OT w Berlinie. Pierwszy z referatów tej sesji traktował o rezultatach dotychczasowych badań odnośnie do największej z fabryk, wspomnianej wyżej spółki A/S Nordag, znajdującej się w Sauda (okręg Rogaland). Zaprezentował go drugi z magistrantów NTNU - Tore B. Dahl. Tematem związanym z branżą ekonomiczną było także wystąpienie dr Matsa Ingulstada z NTNU, w którym przedstawił związki norweskich przedsiębiorstw z OT-Einsatzgruppe Wiking, wykonujących pod egidą tej organizacji różnorodne prace budowlane na terenie Norwegii. Kolejne dwa referaty odnosiły się stricte do zadań OT w zakresie budowy kolei i dróg w Norwegii. Pierwszy z nich wygłosiła magister historii z NTNU Silje Tjømøe pt. „Na tropie współpracy norweskich kolei państwowych z Niemcami w budowie kolei północnej podczas drugiej wojny światowej" (På sporet av NSBs samarbeid med tyskerne i byggingen av Nordlandsbanen under andre verdenskrig). Drugi z referatów na temat prac drogowych wykonywanych przez OT i norweską dyrekcję ds. dróg (Veidirektoratet) przedstawił magistrant w/w uczelni Anders Fagerbakk.

W drugim dniu obrad (sesje III i IV) tematyka wystąpień skoncentrowana była wokół najważniejszej części projektu badawczego, a mianowicie 
kwestii wykorzystywania miejscowej i zagranicznej siły roboczej przez OT-Einsatzgruppe Wiking. Jako pierwszy w sesji III wygłosił referat stypendysta z NTNU Gunnar Hatlehold, w którym naświetlił szczegółowo problem przymusowego zatrudniania norweskich obywateli przez OT. Drugi z referentów, stypendysta z Uniwersytetu Agder w Kristiansand, Jan Egil Hansen, skupił się nad sprawą podobieństw i różnic w sposobie zatrudniania norweskich robotników do prac przymusowych przez pronazistowską Służbę Pracy (Arbeidstjeneste) i OT. Kolejny referat wygłosiła Marianne Neerland Soleim - pracownik naukowy z Muzeum Falstad w Levanger (północny Trondelag). W swoim wystąpieniu zaprezentowała problem rywalizacji pomiędzy OT, SS i Wehrmachtem w zatrudnianiu sowieckich jeńców wojennych do prac na terenie Norwegii. Czwarty referat - o Polakach wywożonych do prac OT, głównie na północ Norwegii, wygłosiła Emilia Denkiewicz-Szczepaniak - historyk z Katedry Skandynawistyki Uniwersytetu Gdańskiego. W referacie wskazała na różnice w sposobach rekrutacji polskich robotników na ziemiach polskich pod okupacją niemiecką i w Generalnym Gubernatorstwie, także drogi ich wywózki, rodzaj wykonywanych przez nich prac przymusowych na dalekiej północy oraz warunki zatrudnienia.

Ostatnią, IV sesję drugiego dnia obrad rozpoczął Tomislav Dulic - historyk z Uniwersytetu w Uppsali (Szwecja). Zaprezentował rezultaty swoich badań nad kwestią przymusowego zatrudniania jugosłowiańskich jeńców wojennych i robotników w Norwegii, skupiając się głównie na geograficznej i statystycznej analizie. Bardziej rozszerzony przekaz odnośnie jugosłowiańskich jeńców wojennych zaprezentował pracownik naukowy Narviksenteret, Michael Stokke w referacie pt. „Jugosłowiańscy jeńcy wojenni w pracy dla OT i norweskiej państwowej służby drogowej”. Kolejny referat w wykonaniu Ewy Ditte-Donat z Muzeum Nordlandu w Steigen (Nordlandsmuseet Steigen) dotyczył warunków pracy sowieckich jeńców wojennych przy budowie dwóch ciężkich baterii przybrzeżnych w Trondenes koło Harstad i na wyspie Engeløy blisko Lofotów. Ostatni referat przedstawiający problem zatrudnienia robotników przymusowych $\mathrm{w}$ kopalniach rud żelaza, siarki, miedzi, molibdenu na terenie całej Norwegii przedstawili profesor NTNU Pål Sandvik i jego magistrant Andreas Dugstad.

Wygłoszone referaty spotkały się z dużym zainteresowaniem słuchaczy, czego najlepszym dowodem było wiele zadawanych pytań i dyskusja. Wszystkie referaty w rozszerzonej wersji zostaną opublikowane w specjalnym opracowaniu pokonferencyjnym. 